\title{
PENINGKATAN KOMPETENSI GURU DALAM PENYUSUNAN RENCANA PELAKSANAAN PEMBELAJARAAN MELALUI SUPERVISI AKADEMIK DI SMP NEGERI 1 SOOKO
}

\section{THE IMPROVEMENT OF TEACHER COMPETENCY IN PREPARING LEARNING IMPLEMENTATION PLAN THROUGH ACADEMIC SUPERVISION IN SMP NEGERI 1 SOOKO}

\author{
Mochamad Sayudi* \\ SMP Negeri 1 Sooko Mojokerto, Indonesia \\ mochamad_sayudi@yahoo.co.id \\ *penulis korespondensi
}

\begin{tabular}{ll}
\hline Info Artikel & ABSTRAK \\
\hline Sejarah artikel: & Tujuan utama dari penelitian ini adalah untuk membantu meningkatkan \\
Diterima: & kompetensi paedagogik guru-guru di SMP Negeri 1 Sooko dalam menyusun \\
12 Desember 2019 & rencana pelaksanaan pembelajaran (RPP) yang sesuai dengan standar \\
Direvisi: & kompetensi masing-masing. Hal tersebut dikarenakan keberhasilan dalam \\
23 Desember 2019 & proses belajar mengajar tidak lepas dari perencanaan pembelajaran yang \\
Disetujui: & disusun oleh guru sebelum melaksanakan pembelajaran. Salah satu langkah \\
20 Januari 2019 & yang bisa digunakan adalah supervisi akademik. Hasil penelitian ini \\
& menunjukkan bahwa supervisi akademik dapat meningkatkan kompetensi \\
Kata kunci: & guru dalam menyusun rencana pelaksanaan pembelajaran (RPP). \\
supervisi akademik, & Berdasarkan penilaian, penyusunan RPP dari rata-rata 68,4 pada prasiklus \\
RPP & meningkat menjadi 71,3 pada siklus I. Berdasarkan tingkat ketuntasannya, \\
& terjadi peningkatan dari 40,9\% pada prasiklus menjadi 61,3\% pada siklus I. \\
& Hal tersebut belum memenuhi kriteria keberhasilan sehingga dilakukan \\
& penelitian siklus II. Kemudian, didapatkan nilai rata-rata kompetensi guru \\
dalam menyusun rencana pelaksaan pembelajaran 74,00 dan berdasarkan
\end{tabular}

\begin{tabular}{|c|c|}
\hline Article Info & ABSTRACT \\
\hline Article history: & The main objective of this research is to improve the pedagogical \\
\hline Received: & competence of teachers in SMP Negeri 1 Sooko, in preparing Learning \\
\hline 12 December 2019 & Implementation Plan that is in accordance with their respective competency \\
\hline Revised: & standards, because success in the teaching and learning process cannot be \\
\hline 23 December 2019 & separated from the learning planning which is prepared by teacher before \\
\hline Accepted: & carrying out learning. One step that can be used is academic supervision. \\
\hline 20 January 2020 & $\begin{array}{l}\text { The results of this study indicate that academic supervision can improve } \\
\text { teacher competency in developing learning implementation plans (RPP). }\end{array}$ \\
\hline Keywords: & Based on the assessment of the preparation of lesson plans from an average \\
\hline academic supervision, & of 68.4 in the pre-cycle increased to 71.3 in the first cycle. Based on the \\
\hline learning & completeness level of $40.9 \%$ in the pre-cycle increased to $61.3 \%$ in the first \\
\hline implementation & $\begin{array}{l}\text { cycle. It does not meet the success criteria, so cycle } 11 \text { research was carried } \\
\text { out and the average teacher competency score in preparing the learning }\end{array}$ \\
\hline
\end{tabular}

Copyright (C) 2020, Stilistika: Jurnal Pendidikan Bahasa dan Sastra DOI: http://dx.doi.org/10.30651/st.v13i1.3773 


\section{PENDAHULUAN}

Pendidikan adalah upaya yang secara sadar dirancang untuk membantu seseorang atau sekelompok orang dalam mengembangkan ilmu pengetahuan, pandangan hidup, sikap hidup, dan keterampilan hidup baik yang bersifat manual individual maupun sosial (Sagala, 2006:1). Upaya memperbaiki dan meningkatkan mutu pendidikan harus senantiasa dilaksanakan tanpa henti dengan agenda reformasi yang telah, sedang, dan akan dilaksanakan. Reformasi pendidikan adalah pembangunan pendidikan dengan memperbaiki pola hubungan sekolah dengan lingkungannya dan dengan pemerintah, pengembangan, mnejerial, pemberdayaan guru dan meningkatkan kekayanaan model model pembelajaran. Suparno (2008:1) mengemukakan bahwa mutu pendidikan Indonesia bukan hanya ditentukan dari pemerintah pusat, tetapi terlebih pada para guru dan dosen serta administrator lapangan yang mau selalu mengadakan refleksi, evaluasi tentang apa yang mereka lakukan dan mengadakan perubahan demi kemajuan praktik pendidikan.

Proses pembelajaran adalah merupakan suatu sistem. Pencapaian standar proses untuk meningkatkan kualitas pendidikan (proses pembelajaran) dapat dimulai dari menganalisis setiap komponen yang dapat mempengaruhi proses pembelajaran. Sanjaya (2008:13) menyatakan komponen yang selama ini dianggap sangat mempengaruhi proses pendidikan adalah komponen guru. Guru yang professional dan efektif merupakan kunci keberhasilan proses belajar mengajar.

Sebagai seorang yang profesional, guru harus memahami dengan baik akan apa yang harus dilakukannya dalam melaksanakan tugas dan tanggung jawabnya sebagai guru. Sesuai dengan Permendikbud RI No 15 Tahun 2018 Pasal 3 Ayat 1 tentang Pemenuhan Beban Kerja Guru, Kepala Sekolah dan Pengawas Sekolah, ada lima tugas utama yang harus dilakukan oleh guru yakni (a) merencanakan pembelajaran atau pembimbingan, (b) melaksanakan pembelajaran atau pembimbingan, (c) menilai hasil pembelajaran atau pembimbingan, (d) membimbing dan melatih peserta didik dan (e) melaksanakan tugas tambahan yang melekat pada pelaksanaan kegiatan peembelajaran sesuai dengan beban kerja guru. Dari kelima tugas utama yang harus dilakukan guru tersebut, perencanaan pembelajaran memainkan peranan yang sangat vital karena pelaksanaan dan penilaian pembelajaran akan terlaksana dengan baik apabila guru mampu membuat perencanaan pembelajaran dengan baik.

Sudjana (2012:34) mengatakan bahwa perencanaan pembelajaran adalah rancangan tentang apa yang akan dikerjakan guru dalam melaksanakan pembelajaran. Dengan kata lain perencanaan pembelajaran adalah proyeksi atau perkiraan kegiatan yang akan dilaksanakan guru pada saat guru membelajar peserta didik. Perencanaan pembelajaran yang dituangkan di dalam RPP menjadi barometer apakah pembelajaran yang akan dilaksanakan guru bisa mencapai hasil yang maksimal didalam membelajarkan peserta didik untuk menguasai kompetensi-kompetensi yang diajarkan baik yang berkaitan dengan penguasaan kompetensi sikap, pengetahuan, dan keterampilan. 
Kajian yang dilakukan oleh Depdiknas, Bappenas, dan Bank Dunia (1999: 47) menemukan bahwa guru merupakan kunci penting dalam keberhasilan memperbaiki mutu pendidikan, dikemukakannya, "Guru merupakan titik sentral dalam usaha mereformasikan pendidikan dan mereka menjadi kunci keberhasilan setiap usaha peningkatan mutu pendidikan dan hanya akan berarti apabila melibatkan guru" (Tim Dosen Administrasi Pendidikan UPI, 2008). Untuk itu, kualitas mengajar yang dilakukan oleh guru harus mendapatkan pengawasan dan pembinaan yang terus menerus dan berkelanjutan yang dilakukan oleh kepala sekolah selaku pimpinan. Aktifitas pengerahan dan bimbingan yang dilakukan kepala sekolah kepada guru-guru yang berkaitan dengan kegiatan belajar para siswa untuk memperbaiki situasi belajar mengajar di kelas inilah yang dimaksud dengan supervisi (Tim Dosen Administrasi Pendidikan UPI, 2008).

Salah satu supervisi yang bisa digunakan untuk membantu guru dalam kegiatan mengajar adalah supervisi akademik. Kompetensi supervisi akademik intinya adalah membina guru dalam meningkatkan mutu proses pembelajaran. Oleh sebab itu, sasaran supervisi akademik adalah guru dalam proses belajar mengajar (pembelajaran). Materi pokok dalam proses pembelajaran adalah penyusunan silabus dan RPP, pemilihan strategi, metode, teknik pembelajaran, penggunaan media dan teknologi informasi dalam pembelajaran, menilai proses dan hasil pembelajaran serta penelitian tindakan kelas.

Kenyataan yang ditemukan dewasa ini masih banyak guru pada satuan pendidikan yang belum memiliki kemampuan yang memadai untuk menyusun rencana pelaksanaan pembelajaran secara lengkap dan sistematis. Kurangnya kemampuan guru tersebut bisa dilatarbelakangi oleh beberapa faktor, antara lain: (1) kurangnya pemahaman guru tentang pentingnya perananan perencanaan pembelajaran; (2) kurang optimalnya pelaksanaan kegiatan supervisi akademik dalam membimbing dan membina guru dalam penyusunan rencana pelaksaan pembelajaran.

diberikan memperngaruhi hasil pendidikan di sekolah. Oleh sebab itu, perlu adanya solusi dan tindakan nyata dari Kepala sekolah sebagai penanggung jawab keberhasilan pendidikan di sekolahnya. Sehubungan dengan kondisi di atas maka peneliti mengambil judul Peningkatan Kompetensi Guru Dalam Penyusunan Rencana Pelaksanaan Pembelajaraan Melalui Supervisi Akademik di SMP Negeri 1 Sooko.

\section{METODE}

Pendekatan dalam penelitian ini merupakan pendekatan penelitian tindakan sekolah (PTS). Suhardjono (2008:10) menyatakan penelitian tindakan banyak dilakukan baik oleh guru, kepala sekolah maupun pengawas. Apabila dilakukan guru umum disebut sebagai Penelitian Tindakan Kelas (PTK). Sedangkan apabila dilakukan oleh kepala sekolah atau pengawas sekolah, disebut sebagai Penelitian Tindakan Sekolah (PTS).

Jenis penelitian ini merupakan penelitian tindakan sekolah, karena dari analisis dan refleksi setiap akhir kegiatan dilakukan tindakan yang berdasarkan hasil analaisis dan refleksi yang dibuat sebelumnya. Ciri penelitian 
tindakan sekolah ini adalah digunakannya prosedur kerja siklus dalam suatu penelitian yang terdiri dari 4 tahap, yaitu perencanaan, tindakan, observasi, dan refleksi.

Pada penelitian ini peneliti bertindak sebagai instrumen kunci sekaligus pengumpul data. Oleh karena itu, kehadiran peneliti di lapangan mutlak diperlukan. Keterlibatan pihak lain hanya bersifat konsultatif dalam mempertajam persoalan-persoalan pembelajaran yang dihadapi guru sekiranya layak untuk diuraikan melalui penelitian tindakan sekolah. Selain instrumen kunci juga digunakan instrumen lain yaitu dokumentasi.

Metode yang digunakan dalam penelitian ini adalah metode deskriptif, dengan menggunakan teknik persentase untuk melihat peningkatan yang terjadi dari siklus ke siklus. "Metode deskriptif dapat diartikan sebagai prosedur pemecahan masalah yang diselidiki dengan menggambarkan/ melukiskan keadaan subjek/objek penelitian (seseorang, lembaga, masyarakat, dan lain-lain) pada saat sekarang berdasarkan fakta-fakta yang tampak atau sebagaimana adanya (Nawawi, 1985: 63). Prosedur dalam penelitian ini mencakup langkah-langkah : (1) perencanaan, (2) pelaksanaan, (3) pengamatan, dan (4) refleksi sebagaimana digambarkan pada Gambar 1 berikut.

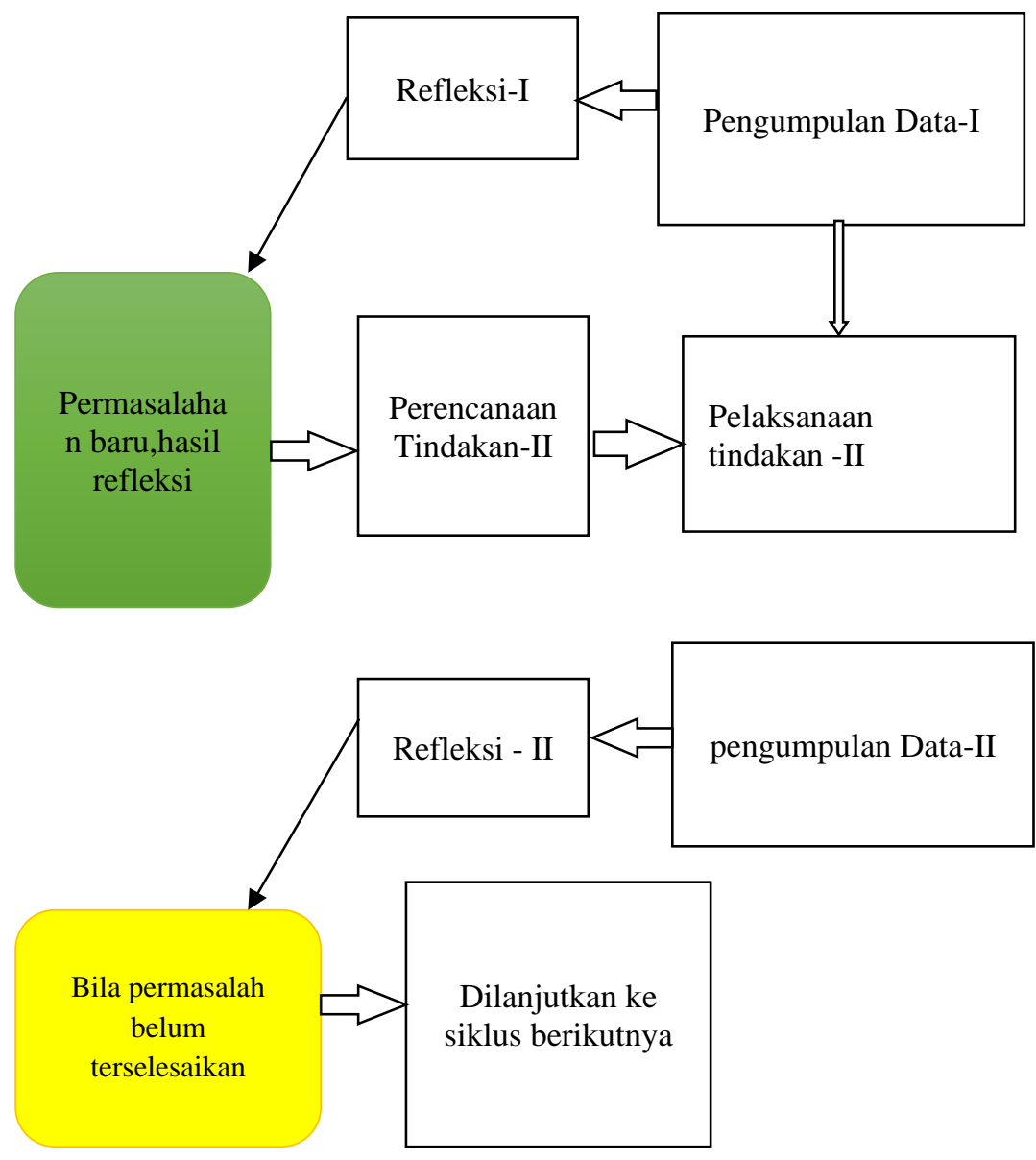

Gambar 1. Langkah-langkah Penelitian 
HASIL DAN PEMBAHASAN

Kompetensi guru SMP Negeri 1

Sooko dalam penyusunan Rencana Pelaksanaan Pembelajaran (RPP) masih rendah. Hal ini dapat dilihat dari kemauan guru untuk membuat RPP sendiri masih kurang. RPP yang digunakan guru dalam pembelajaran masih buatan orang lain/penerbit tertentu, download dari internet, atau copy paste buatan teman hanya diedit nama sekolah dan guru serta kepala sekolah. Akibatnya, terdapat hal yang tidak sesuai saat diterapkan di sekolah tempat guru mengajar, seperti ketidaksesuaian dengan media yang digunakan, pendekatan pembelajaran yang diterapkan, buku sumber yang digunakan, dan sebagainya. Dari hasil pengamatan kompetensi menyusun RPP yang dilakukan oleh Kepala Sekolah, hasilnya juga belum menggembirakan. Di SMP Negeri 1 Sooko ada 44 guru mata pelajaran, ketika dilakukan pengamatan kompetensi menyusun RPP pada kondisi awal, ternyata nilai rata-ratanya baiknya hanya dicapai oleh 18 guru atau sebesar 40,9\%.

Gambaran kondisi awal kompetensi menyusun rencana pelajaran dapat dilihat pada tabel berikut ini:

Tabel 1. Kompetensi Menyusun RPP pada Prasiklus

\begin{tabular}{|c|c|c|}
\hline No & Kompetensi & $\begin{array}{c}\text { Nilai Kompetensi } \\
\text { Menyusun RPP }\end{array}$ \\
\hline 1. & Terendah & 62,4 \\
\hline 2. & Tertinggi & 77,6 \\
\hline 3. & Rerata & 68,4 \\
\hline
\end{tabular}

Untuk mengatasi permasalahan guru yaitu rendahnya kompetensi guru dalam menyusun RPP, Kepala Sekolah dapat mengadakan supervisi akademik yang terencana dengan baik, dijadwal waktu pelaksanaannya, dilaksanakan dengan baik, dan ditindaklanjuti dengan baik pula. Kepala sekolah menyatakan bahwa dalam menjalankan tugasnya berpedoman pada program sekolah yang dikenal sebagai program kerja tahunan (RKT). Dalam program kerja tahunan tercantum kegiatan supervisi, salah satunya adalah supervisi akademik disusun oleh kapala sekolah bersama dengan dewan guru.

\section{Siklus I}

Siklus 1 dalam penelitian ini dilaksanakan dalam dua kali pertemuan, yaitu tanggal 6 September 2018 dan 14 September 2018. Pada siklus ini meliputi empat tahap, yakni (1) perencanaan, (2) pelaksanaan, (3) pengamatan atau observasi, dan (4) refleksi. Masing-masing tahap dipaparkan sebagai berikut:

1. Perencanaan

Tahap perencanaan meliputi kegiatan:

a) Menyiapkan daftar hadir

b) Menyiapkan kisi-kisi penilaian RPP

c) Lembar Penilaian RPP

d) Deskripsi lembar penilaian RPP

e) Membuat rekapitulasi hasil penilaian RPP

f) Menyiapkan rencana supervisi akademik

2. Pelaksanaan

Pelaksanaan tindakan yang dilakukan pada siklus 1 adalah :

a) Mempersiapkan ruangan untuk pertemuan klasikal, guru dibuat dalam dua kelompok, agar ada kerjasama antar guru dalam mengerjakan tugas-tugas, diharapkan ada kerjasama antar guru, sehingga guru yang kurang mampu bisa belajar pada teman guru yang mampu (yang sudah mendapatkan skor baik). 
b) Melakukan pembinaan tentang peningkatan kemampuan guru dalam menyusun RPP secara klasikal.

3. Pengamatan

Objek yang diamati dalam penelitian ini adalah:

a) Pelaksanaan supervisi kepala sekolah terhadap kompetensi guru dalam menyusun rencana pelaksanaan pembelajaran secara individual, peneliti bersama teman sejawat/kolaborator. Melakukan pengamatan sesuai lembar pengamatan yang telah dibuat. Pengamatan dilaksanakan dengan dibantu seorang kolaborator yakni Ibu Sekartami selaku wakil kepala sekolah bidang kurikulum. Pengamatan ini dilaksanakan pada hari Jum'at, 14 September 2018.

b) Tanggapan guru terhadap supervisi kepala sekolah merespon dengan sangat baik, dengan adanya supervisi kepala sekolah dapat membantu dalam menyusun RPP dengan baik dan benar.

c) Kondisi lingkungan tempat penelitian berlangsung pada awal pelaksanaan supervisi kurang mendukung karena di lingkungan tempat penelitian sebagian besar guru tidak membuat RPP yang disesuaikan dengan kondisi peserta didik di sekolahnya, hanya mengcopy paste dari MGMP atau download dari internet. Tanpa mempelajari bagaimana RPP yang ideal untuk diterapkan di sekolahnya. Setelah diadakan supervisi sebagian besar guru sudah membuat RPP dengan baik dan benar dan disesuaikan dengan kondisi di sekolah.

Setelah supervisi dan pengamatan dilakukan pada saat proses pelaksanaan tindakan, hasil pengamatan berupa data hasil pengamatan kompetensi guru dalam penyusunan RPP meningkat, berikut ini adalah hasil pengamatan kompetensi menyusun RPP pada siklus 1 .

Tabel 2. Kompetensi menyusun RPP pada Siklus 1

\begin{tabular}{|c|c|c|}
\hline No & Kompetensi & $\begin{array}{c}\text { Nilai Kompetensi } \\
\text { Menyusun RPP }\end{array}$ \\
\hline 1. & Terendah & 65,9 \\
\hline 2. & Tertinggi & 80,0 \\
\hline 3. & Rerata & 71,3 \\
\hline
\end{tabular}

4. Refleksi

Refleksi adalah merenungkan hasil pelaksanaan tindakan, untuk mengetahui kekurangan pada pelaksanaan siklus 1, kemudian diperbaiki pada siklus selanjutnya.

Berdasarkan tabel 1 dan 2, menunjukkan adanya peningkatan kompetensi dari kondisi awal rata-rata 68,4 menjadi 71,3 dan tingkat ketuntasannya mencapai $61,3 \%$, meningkat $20,4 \%$ dari $40,9 \%$ pada kondisi awal. Kekurangan kompetensi menyusun RPP pada siklus 1 antara lain (1) Aspek tujuan pembelajaran, belum menggambarkan proses dan hasil belajar yang diharapkan dicapai oleh peserta didik sesuai dengan kompetensi dasar. (2) Aspek materi, hanya ditulis materi pokok saja, belum ditulis dalam bentuk butir-butir sesuai dengan rumusan indikator sesuai dengan rumusan indikator pencapaian kompetensi, dan pada lampiran belum ada penjabaran dari materi pokok (3) Aspek metode pembelajaran, belum bervariasi, cenderung metode ceramah. (4) Aspek Kegiatan Pembelajaran, belum dilakukan secara sistematis dan belum mengintegrasikan PPK (Penguatan Pendidikan Karakter), Literasi, dan 4C (creative, critical thinking, communicative, dan collaborative. (5) Aspek penilaian hasil 
belajar, pada lampiran belum disertai kunci jawaban dan pedoman penilaian, serta lembar kerja dan lembar pengamatan kegiatan pembelajaran. Oleh karena itu perlu pembinaan supervisi akademik untuk meningkatkan kompetensi tersebut pada siklus berikutnya.

\section{Siklus 2}

Siklus 2 dalam penelitian ini dilaksanakan dalam dua kali pertemuan yaitu tanggal 25 September 2018 dan 5 Oktober 2018. Pada siklus 2 ini meliputi empat tahap yaitu perencanaan, pelaksanaan, pengamatan, dan refleksi, dengan perincian sebagai berikut:

\section{Perencanaan}

Beberapa aspek yang akan diperbaiki dalam siklus ini berdasarkan pengamatan pada siklus 1 adalah sebagai berikut:

1) Aspek tujuan pembelajaran.

2) Aspek materi pembelajaran.

3) Aspek metode pembelajaran.

4) Aspek kegiatan pembelajaran.

5) Aspek penilaian hasil belajar.

Pelaksanaan pembinaan pada siklus ini direncanakan secara berkelompok. Dari 44 guru dipilih beberapa guru yang akan dijadikan ketua kelompok. Pemilihan ini dilakukan dengan mengambil 4 guru yang mempunyai skor tinggi agar dapat membantu guru yang mendapatkan skor rendah. Sebelum pelaksanaan peneliti dibantu oleh kolaborator melakukan pembinaan kepada guru yang ditunjuk sebagai pendamping kelompok pada hari Jumat, 21 September 2018.

2. Pelaksanaan

Peneliti dibantu oleh kolaborator melakukan pembinaan secara kelompok tentang beberapa aspek yang harus diperbaiki, diantaranya sebagai berikut:

a) Aspek tujuan pembelajaran yang menggambarkan hasil belajar yang diharapkan oleh peserta didik sesuai dengan kompetensi dasar.

b) Aspek materi ditulis sesuai dengan rumusan indikator, indikator pencapaian kompetensi.

c) Aspek metode pembelajaran harus bervariasi.

d) Aspek kegiatan pembelajaran dilakukan secara sistematis, melalui proses eksplorasi, elaborasi, dan konfirmasi.

e) Aspek penilaian hasil belajar disertai kunci jawaban, pedoman penilaian, lembar kerja, dan lembar pengamatan.

Pada tahap ini perbaikan juga

dilakukan dengan memberi pembekalan dan materi yang disampaikan oleh Bapak Ruslan Affandi selaku pengawas sekolah. Kegiatan ini dilaksanakan pada hari Selasa, tanggal 25 September 2018 dan dihadiri oleh 44 guru selaku subjek penelitian.

3. Pengamatan

Objek yang diamati dalam penelitian ini adalah sebagai berikut:

a) Pelaksanaan supervisi kepala sekolah terhadap kompetensi guru dalam menyusun rencana pelaksanaan pembelajaran secara individual, peneliti bersama teman sejawat/kolaborator melakukan pengamatan sesuai lembar pengamatan yang telah dibuat.

b) Tanggapan guru terhadap supervisi kepala sekolah merespon dengan sangat baik, dengan adanya supervisi kepala sekolah dapat membantu dalam menyusun RPP dengan baik dan benar.

c) Kondisi lingkungan tempat penelitian berlangsung pada awal 
pelaksanaan supervisi kurang mendukung karena di lingkungan tempat penelitian sebagian besar guru tidak membuat RPP yang disesuaikan dengan kondisi peserta didik di sekolahnya, hanya mengcopy paste dari MGMP atau download dari internet. Tanpa mempelajari bagaimana RPP yang ideal untuk diterapkan di sekolahnya. Setelah diadakan supervisi siklus 2 sebagian besar guru sudah membuat RPP dengan baik dan benar.

Setelah supervisi dan pengamatan dilakukan pada saat proses pelaksanaan tindakan, hasil pengamatan berupa data hasil pengamatan kompetensi guru dalam peenyusunan RPP meningkat dari siklus 1, berikut ini adalah hasil pengamatan kompetensi menyusun RPP pada siklus 2:

Tabel 3. Kompetensi Menyusun RPP pada Siklus 2

\begin{tabular}{|c|c|c|}
\hline No & Kompetensi & $\begin{array}{l}\text { Nilai Kompetensi } \\
\text { Menyusun RPP }\end{array}$ \\
\hline 1. & Terendah & 67,6 \\
\hline 2. & Tertinggi & 82,4 \\
\hline 3. & Rerata & 74,1 \\
\hline
\end{tabular}

\section{Refleksi}

Refleksi siklus 2 yaitu membandingkan hasil kompetensi menyusun rencana pelaksanaan siklus 1 dengan siklus 2 , untuk melihat hasil tindakan pada silus 2 ini. Berdasarkan tabel di atas, melalui supervisi akademik menunjukkan adanya peningkatan dari siklus 1 rata-rata 71,3 menjadi 74,1 dan tingkat ketuntasannya mencapai $84 \%$, meningkat $22,7 \%$ dari $61,3 \%$ pada siklus 1. Pada indikator kompetensi mencari dan membaca referensi serta kemauan meningkatkan kompetensi sudah mengalami peningkatan, dan sudah memenuhi indikator kinerja sebesar $80 \%$. Ini terbukti melalui pembinaan supervisi akademik dapat meningkatkan kompetensi guru dalam penyusunan rencana pelaksanaan pembelajaran (RPP).

Setelah dilaksanakan siklus 1 dan siklus 2 dari rangkaian penelitian ini maka dapat memberikan hasil pelaksanaan keseluruhan siklus. Sebelum siklus 1 dilaksanakan, kondisi awal kompetensi guru dalam menyusun rencana pelaksanaan pembelajaran dapat dikatakan rendah. Hal ini dapat dilihat dari RPP yang telah disusun oleh guru masih mencontoh RPP yang ada yang dibuat oleh penerbit tertentu, terkadang hanya copy paste, guru enggan membuat sendiri RPP, dan RPP yang dibuat belum sesuai dengan standar proses. Berdasarkan kondisi awal ini peneliti berinisiatif untuk meningkatkan kompetensi menyusun RPP melalui supervisi akademik.

Pada siklus 1 peneliti sudah melaksanakan Supervisi Akademik secara klasikal, kemudian guru diberikan tes untuk menyusun RPP. Setelah diadakan pengamatan dan penilaian menunjukkan adanya peningkatan kompetensi guru dalam penyusunan RPP dari kondisi awal rendah ke siklus 1 menjadi agak tinggi. Hal ini diunjukkan adanya peningkatan dari kondisi awal rata-rata 68,4 menjadi 71,3 dan tingkat ketuntasannya mencapai $61,3 \%$, meningkat 20,4 dari $40,9 \%$ pada kondisi awal. Pada indikator kompetensi mencari dan membaca referensi serta kemauan meningkatkan kompetensi masih kurang, oleh karena itu perlu pembinaan supervisi akademik untuk meningkatkan kompetensi tersebut pada siklus berikutnya.

Pada siklus 2 peneliti sudah melaksanakan Supervisi Akademik 
secara individual, kekurangan pada kompetensi menyusun rencana pelaksanaan pembelajaran dapat diperbaiki pada siklus 2, sehingga hasil pada siklus 2 meningkat dari siklus 1 agak tinggi ke siklus 2 menjadi cukup tinggi. Ini ditunjukkan dari rata-rata 71,3 menjadi 74,1 dan tingkat ketuntasannya mencapai $84 \%$, meningkat $22,7 \%$ dari $61,3 \%$ pada Siklus 1. Peningkatan ini menunjukkan keberhasilan supervisi akademik dalam meningkatkan kompetensi menyusun rencana pelaksanaan dan sudah mencapai indikator pencapaian kompetensi $80 \%$.

Strategi

Meningkatkan

Keterampilan Supervisi Akademik Kepala Sekolah Melalui Pendampingan Korwas Oleh: Ruslan Affandi, S.Pd., M.Pd. (Pengawas Kabupaten Mojokerto). Supervisi akademik dapat menemukan akar permasalahan dalam kegiatan belajar mengajar. Supervisi akademik membantu guru mengatasi kesulitan dalam mengelola kegiatan belajar mengajar.

Kompetensi guru dalam penyusunan RPP dari kondisi awal, siklus 1 dan siklus 2 ditujukkan pada tabel berikut ini:

Tabel 4. Kompetensi Menyusun RPP pada Prasiklus, Siklus 1 dan Sikuls 2

\begin{tabular}{|c|l|c|c|c|}
\hline No & Kompetensi & Prasiklus & $\begin{array}{c}\text { Siklus } \\
\mathbf{1}\end{array}$ & $\begin{array}{c}\text { Siklus } \\
\mathbf{2}\end{array}$ \\
\hline 1. & $\begin{array}{l}\text { Nilai } \\
\text { Terendah }\end{array}$ & 62,4 & 65,9 & 67,6 \\
\hline 2. & $\begin{array}{l}\text { Nilai } \\
\text { Tertinggi }\end{array}$ & 77,6 & 80,0 & 82,4 \\
\hline 3. & $\begin{array}{l}\text { Nilai Rata- } \\
\text { Rata }\end{array}$ & 68,4 & 71,3 & 74,00 \\
\hline 4. & Ketuntasan & $40,9 \%$ & $61,3 \%$ & $84 \%$ \\
\hline
\end{tabular}

Dari data di atas dapat digambarkan dalam grafik berikut:

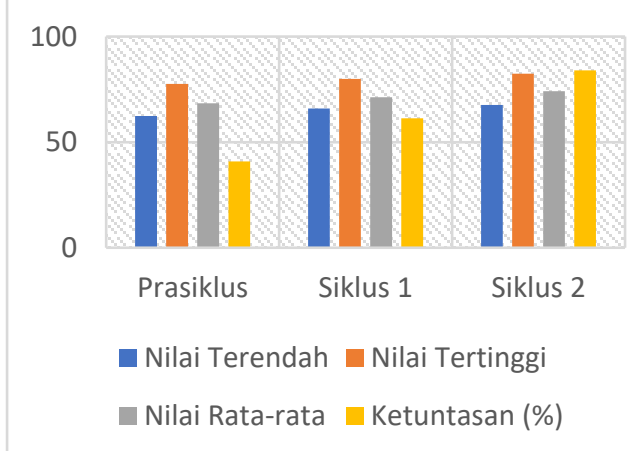

Gambar 2. Grafik Hasil Penelitian

\section{PENUTUP}

Penerapan supervisi akademik dapat meningkatkan kompetensi guru dalam penyusunan Rencana Pelaksanaan Pembelajaran (RPP). Berdasarkan penilaian penyusunan RPP dari rata-rata 71,3 pada siklus I meningkat menjadi 74,1 pada siklus II. Nilai ini mengalami peningkatan dari rata-rata 68,4 pada prasiklus. Berdasarkan tingkat ketuntasan kompetensi guru dalam penyusunan Rencana Pelaksaaan Pembelajaran (RPP) sebesar $61,3 \%$ pada siklus I meningkat menjadi $84 \%$ pada siklus II dari banyaknya guru yang mencapai standar ketuntasan minimum yaitu 70 . Peningkatan ini menunjukkan keberhasilan supervisi akademik dalam meningkatkan kompetensi menyusun rencana pelaksanaan dan sudah mencapai indikator pencapaian kompetensi $80 \%$.

Terdapat beberapa perbaikan terhadap siklus I yang dilakukan pada siklus II, antara lain strategi meningkatkan keterampilan supervisi akademik melalui pendampingan pengawas sekolah oleh Bapak Ruslan Affandi (Pengawas Kabupaten Mojokerto). Supervisi akademik dapat menemukan akar permasalahan dalam kegiatan belajar mengajar. Supervisi akademik membantu guru mengatasi 
kesulitan dalam mengelola kegiatan belajar mengajar.

Berdasarkan paparan data, temuan penelitian dan pembahasan yang diperoleh dari penerapan supervisi akademik yang dapat meningkatkan kompetensi guru dalam penyusunan Rencana Pelaksanaan Pembelajaran (RPP), peneliti memberikan saran sebagai berikut:

1) Motivasi dalam diri guru yang sudah tertanam hendaknya terus dipertahankan dan ditingkatkan khususnya dalam penyusunan RPP.

2) Karena RPP merupakan pedoman dalam melaksanakan pembelajaran, maka hendaknya RPP yang disusun mengandung komponen - komponen RPP secara lengkap dan baik.

3) Dokumen RPP hendaknya dibuat minimal rangkap dua, satu untuk arsip sekolah dan satu untuk pegangan guru dalam melaksanakan proses pebelajaran.

Kekurangan dalam penelitian ini adalah perangkat pembelajaran yang dinilai masih meliputi rencana pelaksanaan pembelajaran, belum perangkat pembelajaran atau media pembelajaran yang lainnya. Dengan demikian, diharapkan untuk peneliti selanjutnya dapat memperbaiki dan menindaklanjuti kekurangan dalam penelitian ini.

\section{DAFTAR PUSTAKA}

Arikunto, S. (2006). Metode Penelitian Kualitatif. Jakarta: Bumi Aksara

Nawawi, Hadari. (1985). Metode Penelitian Bidang Sosial. Yogyakarta: Gadjah Mada University Press.
Peraturan Menteri Pendidikan dan Kebudayaan RI Nomor 15 Tahun $2018 \quad$ Tentang Pemenuhan Bebas Kerja Guru, Kepala Sekolah, dan Pengawas Sekolah,(2019, Januari 15), from http://simpuh.kemenag.go.id/r egulasi/permendikbud_15_18. pdf)

Sagala, Syaiful. (2006). Konsep dan Makna Pembelajaran. Bandung: Alfabeta.

Sanjaya, W. (2008). Strategi Pembelajatan: Berorientasi Standar Proses Pendidikan. Jakarta: Kencana Prenada Media Group

Sudjana, Nana. (2012). Standar Kompetensi Pengawas Dimensi dan Indikator. Jakarta: Binamitra Publishing.

Suhardjono. (2008). Penelitian Tindakan Sekolah sebagai Kegiatan Pengembangan Profesi bagi Pengawas Sekolah. Makalah Pendukung Sajian Lisan pada Workshop Penulisan Karya Ilmiah (KTI) untuk Keniakan Golongan bagi Pengawas, Dinas Pendidikan Pemerintah Kota Depok. Depok, 28 Juli.

Suparno, P. (2008). Action Research: Riset Tindakan untuk Pendidik. Jakarta: PT Gramedia Widiasarana Indonesia.

Tim Dosen Administrasi UPI. (2009). Manajemen Pendidikan. Bandung: Alfabeta. 